\title{
Informal Practices of Inequality in Recruitment in Finland
}

\section{Tuija Koivunen'}

PhD, Researcher, School of Social Sciences and Humanities, University of Tampere, Finland

\section{Hanna Ylöstalo}

PhD, University Lecturer, Gender Studies, University of Turku, Finland

\section{Katri Otonkorpi-Lehtoranta}

Doctoral Candidate, Researcher, Work Research Centre, School of Social Sciences and Humanities, University of Tampere, Finland

\begin{abstract}
In this article, we explore the policies and processes of selection and recruitment from the perspective of equality. Focusing on tacit ideas of the 'ideal worker,' ideal recruitment, and selection that direct the recruitment process, we examine the ways in which implicit ideas and recruitmentrelated settings of daily interaction become informal practices of inequality. In this analysis, we rely on the conceptual framework of inequality regimes. The qualitative analysis of the semi-structured interviews focuses on the categories of gender, ethnicity, and age. We identified three categories of informal practices of inequality, which we have named as recruitment by the book, relocation of responsibility, and recruiting by addressing the difference. The findings suggest that although recruiters follow the legislation concerning equal treatment in recruitment, they do so because they want to avoid problems and possible litigation rather than because they are committed to promoting equality as an end in itself. However, equality promotion requires that gender, ethnicity, and age equality is itself the goal. If equality serves other goals, such as avoiding litigation or boosting business, the everyday practices of recruitment may turn into informal practices of inequality.
\end{abstract}

\section{KEY WORDS}

Informal practices of inequality / recruitment and selection / gender / age / ethnicity

\section{Introduction}

D ecruitment and selection are processes in which job applicants aim to sell their skills, knowledge, qualifications, and experience in order to gain employment and a salary, while employers aim to find the most suitable people for particular jobs and positions. The right person for the job obviously varies from one position to another. For example, some jobs and organizations require a certain type and level of education, whereas in other jobs it may be 'the right attitude' that matters most. These requirements are socially constructed and often explicit, for example, when they are listed in a job advertisement. There are also implicit, socially shared ideas about the ideal worker, although they vary within different work organizations and across different societal contexts (Tienari et al. 2002). These ideas are permeated by social divisions, such as

\footnotetext{
${ }^{1}$ E-mail: tuija.koivunen@uta.fi
} 
gender, age, race or ethnicity, and sexuality. We claim that these ideas have a significant-although often unintentional-effect on recruitment and selection processes, and we argue that they produce inequalities not only in the processes of recruitment and selection, but also in the labor market more generally. These ideas might also prevent the recruiters from finding 'the most suitable person' for the job.

We focus on the processes of recruitment and selection from HR managers', recruitment consultants', and employees' perspective. We see recruitment and selection as social processes in which the recruiters act as gatekeepers; they have the power to grant or deny people access to a certain job or even to the labor market, and they can also prevent individuals from climbing the career ladder (e.g., Carlsson and Rooth 2007; Nordin and Rooth 2009). In this process, socially constructed understandings about the 'ideal worker' (Acker 1990; 1992; Tienari et al. 2002) play a significant role in choosing who is appropriate for the specific position. We understand informal practices as those tacit ideas and implicit settings of day-to-day interaction concerning recruitment in which decision-making, selection, and influencing factors are not structured by a predetermined sets of rules, formal organizational documents, or law, even though they can be informed by these textual materials. When there are systematic disparities between different social groups within these practices, they can be considered informal practices of inequality.

Despite the substantial literature in the field, previous research has focused on recruitment and selection processes as the supply of skills and qualifications and as various methods and ways of recruiting and selecting (Breaugh and Starke 2000; Chapman et al. 2005), whereas the informal social process through which these skills and qualifications are turned into employment with organizations has remained a less studied topic (Keep and James 2010, pp. 1-3). However, the critical human resource management literature has increasingly identified still widely existing inequality and discrimination in recruitment and selection (e.g., Shen et al. 2009).

The Nordic countries have relatively progressive equality policies and legislation. Indeed, the Nordic countries have consistently been ranked the best in the world for gender equality (e.g., World Economic Forum 2013). Nevertheless, the Nordic countries face various persistent problems. In Finland, the site of this study, there is a persistent $20 \%$ wage gap between women and men, the labor market remains segregated by gender, and glass ceilings that prevent women from advancing in their careers have not been broken down, especially in the private sector (e.g., Julkunen 2010). It seems there are certain practices of inequality that the equality policies and legislation are unable to tackle. An interesting nuance of this phenomenon is the fact that the recruiters we interviewed frequently referred to equality legislation, although they misinterpret it rather often. Even though they are aware of equality legislation, they participate in practices of inequality and thus produce these very practices themselves, supposedly unintentionally.

Drawing on a conceptual framework derived from Joan Acker's (2006a; 2009; 2011) inequality regimes, we begin by investigating the kind of tacit ideas about the ideal worker that exist behind the recruitment and selection policy and practices of the recruiters. Next, we ask how these ideas and implicit settings of day-to-day interaction concerning recruitment become informal practices of inequality-that is, practices that sustain inequality in work organizations. In our analysis, we focus on the informal practices of inequality in recruitment and selection that are not made explicit in the recruitment processes, but which nevertheless affect the outcome. Our data consists 
of interviews with HR managers and other experts, involved in staff recruitment at a department store, and interviews with recruitment consultants conducting outsourced recruitment for different clients. We have also utilized the interviews with the department store employees to bring forth their interpretations of the recruitment processes. They represent groups that sometimes are in a disadvantageous situation in recruitment, that is, immigrants and/or young or elderly employees.

Our analysis focuses mainly on three categories of gender, race or ethnicity, and age. Inequality is most widely reported on these grounds in the Finnish labor market (e.g., Ahmad 2002; Larja et al. 2012; Pärnänen 2012; Viitasalo 2011). We share Hae Yeon Choo and Myra Marx Ferree's (2010) clarion call for the analysis of the so-called unmarked groups-that is, the privileged groups-in terms of power. To understand inequality, attention should be given not only to differences from the normative (e.g., woman, black, working class), but also to the unmarked categories (e.g., man, white, middle class), especially in terms of how the more powerful are defined as normative standards (ibid.). By doing this, we also wish to make the unmarked categories explicit in terms of power and privilege, and equality and inequality.

Our overall aim is to show that despite all the effort put into promoting equality in recent decades, equality policy and legislation are somewhat weak when it comes to battling informal practices of inequality, and therefore certain inequalities in the labor market persist. Even though equality legislation distinguishes open and hidden discrimination, it still does not quite grasp the informal practices of inequality. By discussing these informal practices of inequality in recruitment and selection, we participate in the ongoing debate on equality and how it can be promoted in working life.

\section{Gender, age, and race inequalities in recruitment: the Finnish context}

Gender equality legislation in Finland and the other Nordic countries has gradually expanded in focus from anti-discrimination to positive action. Despite relatively progressive gender equality legislation, the progress of equality has still been somewhat modest. At the policy level, promising equality strategies fail to bring about changes-the strategies' transformative potential tends to disappear in the process of implementation. Furthermore, equality legislation is soft, meaning that it is based on recommendations and voluntary practices rather than on prohibitions and sanctions (Kantola 2010). At the organizational level, equality issues often have an 'obligation to yield' (Skjeie and Teigen 2005), which means that measures to promote equality, such as equality planning, are not done properly_if at all-because there is always 'something more important to do.' Equality is also promoted in short projects rather than through persistent and long-term development work (Brunila 2009).

In Finland, the purpose of the Non-discrimination Act (1325/2014) is to prohibit discrimination on the basis of age, ethnic or national origin, nationality, language, religion, belief, opinion, health, disability, sexual orientation, or other personal characteristics. The prohibition of discrimination based on gender is covered by the provisions of the Act on Equality between Women and Men (609/1986). Moreover, the aim of the Act on Equality is to promote equality between women and men, and thus improve the status of women, particularly in working life. Every employer must promote gender equality in working life in a purposeful and systematic manner. 
The Act on Equality states that in order to promote equality between women and men, employers must act in such a way that job vacancies attract applications from both women and men, and they must promote the equitable recruitment of women and men and provide them with equal opportunities for career advancement. The act also states that the employer's actions are deemed discriminatory if the employer, upon employing a person, bypasses a more qualified person of the opposite sex in favor of the person chosen unless the employer's action was for an acceptable reason and not due to gender, or the action was based on significant and acceptable grounds related to the nature of the job or the task. It is also deemed to constitute discrimination if the employer, upon employing a person, acts in such a way that the person finds herself in a less favorable position on the basis of pregnancy, childbirth or some other gender-related reason.

Discrimination is mostly hidden in informal practices of inequality in recruitment and difficult to prove. In addition, recruiters' and job seekers' subjective experiences and interpretations of the selection process and the possible occurrence of discrimination usually differ from each other. Discrimination in the selection policy and processes can be subtle or covert. The subtle discrimination can be mild and/or unconscious, whereas covert discrimination is more malicious and intentional. Both types of discrimination are difficult to recognize, because, for example, in recruitment practices they can occur through non-transparent selection processes (Husu 2002).

According to the observations of employees, discrimination based on gender, having a family, or being pregnant has decreased in Finnish workplaces in recent years. In $2013,3 \%$ of men and $8 \%$ of women observed gender-based unequal treatment or discrimination directed at women in their workplaces. In the case of having a family or pregnancy, the corresponding percentages were 3\% for men and $6 \%$ for women (Quality of Work Life Survey 2013). In Finland, 3\% of men and 6\% of women have noticed discrimination in a recruitment situation in the last five years. The percentages have decreased slightly over the last ten years $(6 \%$ for men and $8 \%$ for women in 2003) (Quality of Work Life Survey 2013; see also Larja et al. 2012, pp. 181-182). Drawing on Swedish data, Åslund and Nordström Skans (2012) show how anonymous job application procedures improved women's and ethnic minorities' chances of advancing to the job interview stage, indicating that employers select applicants for job interview based on gender and ethnicity. The results demonstrate that women clearly benefit from an anonymous hiring process, but the final outcome was not as good for ethnic minorities. Åslund and Nordström Skans suggest that ethnic discrimination is based on prejudice or preferences, and this is why they do not move forward from the job interview stage.

On the basis of Åslund and Nordström Skans' (2012) study, and in light of other recent Nordic studies, ethnic discrimination appears to be more common than gender discrimination. For example, in a recent Finnish study, three times more ethnic discrimination was observed than gender discrimination (Larja et al. 2012, pp. 181-182). Jasinskaja-Lahti et al. (2002, pp. 86-88) have reported that of the seven nationality groups studied, every second immigrant who had applied for a job had experienced discrimination at least once, Somalis and Arabs more often than other groups. A few Nordic studies have utilized experimental methods to study recruitment processes from an ethnic discrimination perspective, and the findings of these studies are all parallel. In Sweden, Carlsson and Rooth (2007) found that individuals with a Swedish name had to apply for an average of ten jobs in order to receive an invitation to a job interview, 
whereas individuals with a Middle Eastern-sounding name had to apply for an average of fifteen jobs before receiving an invitation. This effect is likely to be stronger when jobs are scarce, and the level of discrimination varies across occupations. Rooth's (2010) later experimental study also shows an almost identical result: the probability of being invited to a job interview is lower among applicants with Arab-Muslim names than applicants with Swedish names. A study of the callback rates for Finnish- and Russiannamed applicants proves that applicants with a Russian name need to send twice as many applications as Finnish-named applicants to get invited to a job interview (Larja et al. 2012, pp. 162-165).

In light of these studies it is obvious that the idea of diversity management as an asset of organizations has not yet become popular in Finland. Diversity management originates from the United States, and it has been introduced in a wide range of public and private organizations especially in the Anglo-American countries. Kandola and Fullerton's well-known definition of diversity management describes it thus:

The basic concept of managing diversity accepts that the workforce consists of a diverse population of people. The diversity consists of visible and non-visible differences which will include factors such as sex, age, background, race, disability, personality and workstyle. It is founded on the premise that harnessing these differences will create a productive environment in which everyone feels valued, where their talents are being fully utilized and in which organizational goals are met. $(1998$, p. 7$)$

In the United States, diversity management has been introduced as a substitute to affirmative action policies. It has been more easily accepted by corporate executives and it is much easier to sell to a predominantly white workforce (Lorbiecki and Jack 2000, p. 20). Definitions of diversity management have been dominated by an instrumental and mechanistic rationality, according to which diversity management is a tool to reach organizational goals (Lorbiecki and Jack 2000, p. 19; on economic gains, see Gilbert et al. 1999). Diversity management is not introduced in terms of equal treatmentalthough this is also supposed to be the outcome-but rather in terms of effectiveness and profit-making.

Besides gender and ethnic discrimination, ageism is the third most widely reported form of discrimination experienced in recruitment. According to the Finnish Quality of Work Life Survey (2013), 7\% of women aged 55-65 and 5\% of women aged 16-24 have experienced discrimination in recruitment in Finland, whereas only 1-2\% men in the same age groups have experienced discrimination. Nationally, 'around $10 \%$ of the population have observed age discrimination in their organization or in the behavior of their closest supervisor' (Larja et al. 2012, p. 44).

\section{Recruitment as an organizing process producing inequality}

According to Joan Acker (2009, pp. 208-209; 2011, p. 72), recruitment and selection are examples of processes and practices that contribute to the production of inequality regimes. She $(2006$ b, p. $110 ; 2009 ; 2011)$ argues that all organizations have inequality regimes, even those that are publicly committed to promoting equality. Organizational inequality regimes she defines as 'loosely interrelated practices, processes, actions and 
meanings that result in and maintain class, gender and racial inequalities' (Acker 2006a, p. 443). Thus, inequality is built into organizational dynamics at all levels, and inequality regimes vary according to organization. The inequality regimes are changeable and linked not only to the organization but also to the society. While Acker focuses on class, gender, and racial inequalities, we focus on gender, ethnicity, and age inequalities. By studying inequality regimes, it is possible to explain the organizing processes that create inequality.

The processes and practices that form the basis of the inequality regimes are often informed by different kinds of textual material that is partly created not only in organizations, but also in the wider society, such as legislation. In accordance, recruitment and selection can be considered a complex set of processes and practices that are influenced by different kinds of explicit and implicit, conscious and unconscious, and official and unofficial elements of textual and nontextual materials.

Recruitment and selection practices are permeated by gender, ethnicity, age, and other stereotypes, and these stereotypes contribute to the persistence of inequality (Healy et al. 2011). Studies on discrimination in recruitment and hiring (e.g., Beattie and Johnson 2012; Rooth 2010) have shown that recruiters' attitudes and perceptions of stereotypes often operate at an unconscious level. Therefore, there can be a contradiction between the recruiter's conscious ideas and assumptions of her/his own behavior as a recruiter and her/his actual unconscious practices (Beattie and Johnson 2012, p. 12). Anna Pärnänen (2012) observed job-interviewing employers both deny pursuing an age discrimination policy and also admit to favoring younger job seekers. This might partly explain why official human resources policy at the organizational level and equality acts and legislation at the societal level have not guaranteed gender-, ethnicity-, and age-neutral recruitment and selection practices (Acker 2009, pp. 208-209; Healy et al. 2011).

Recruitment and selection are done either by the employers themselves or increasingly by private employment agencies. According to a survey on recruitment practices at Finnish work organizations (Junnila and Honkaniemi 2010), almost all (96\% of respondents) organizations have experiences of using external expert help in hiring employees. The most common type of help used was a feasibility assessment (61\% of respondents reported using a feasibility assessment always or regularly), the second most common was the use of staffing agencies (always or regularly: 21\%), and the third most common was direct recruitment (always or regularly: 17\%). Thus, outsourced recruitment is a common practice in Finnish work organizations.

Direct recruitment refers to an outsourced assignment that an organization gives to a private employment agency. The aim of the outsourced assignment is to acquire one or more new employees for the client company. At its simplest, the direct recruitment process proceeds with the employment agency identifying the need for the personnel to be recruited; the agency then publishes a job advertisement, selects one or more potential employees from the applicants, and finally presents them to the client. The final decision of whether to hire the applicant is always made by the client. Direct recruitment is used to search for a wide range of employees and to fulfill a number of multilevel tasks. In Finland, direct recruitment is most frequently used in the information and communication technology sector and least used in the public sector. The most important reasons reported for using external expert help relate to supplementing the organization's own skills in recruitment and filling a gap caused by shortages in the organization's own time and personnel resources (Junnila and Honkaniemi 2010, p. 18). 


\section{Research material and analysis}

Our empirical analysis is based on two datasets. The first dataset consists of 31 semistructured research interviews, gathered in 2011-2012, each lasting 1-1.5 hours, recorded at two workplaces, which are part of a larger organization referred to here as 'the Department Store.' The interviewees work at different levels of the organization and have different roles. The primary interviewees (10 persons) are involved in recruitment and they work as senior employees or experts. The secondary interviewees $(21$ persons) are employees not involved in recruitment, but they offer background information on their own recruitment process and experiences. The purpose of the interviews was, firstly, to find out if there were unequal practices and discrimination in the workplace according to the interviewees, and, secondly, to discover the kinds of practices the workplace uses to support equal treatment and prevent discrimination. This article is not all based on a case study of recruitment by department store; rather, the department store provides the employer case within a broader context of recruitment processes in Finland.

The second dataset consists of ten semi-structured interviews gathered in 2013 from three private employment agencies, which do not have a direct relationship with the department store. Each interview lasted about an hour. The interviewees have considerable experience of outsourced direct recruitment, although some of them are senior employees. The others work as HR consultants or recruitment consultants, and two interviewees are responsible for testing job applicants via a skills and personality assessment. For the sake of simplicity, all the interviewees in this dataset are called recruitment consultants.

Our main concern in the recruitment consultants' interviews was to map out the phases of the outsourced recruitment process and to produce knowledge about the assessment of the job applicants' various competences. Inequality in recruitment was not-at least not directly-a topic brought up by the interviewers, but rather by the interviewees. However, this second set of data complements the HR managers' interviews, even though the organizational background of the recruitment processes is different. Although both datasets are produced for different purposes, together they form a rich body of research material that offers a broad and detailed picture of recruitment practices.

The starting point for our analysis of the two datasets was the informal practices of inequality in recruitment, that is, the method by which defining and selecting the ideal worker worthy of recruitment is conducted. The interview as such is a practice, and it may or may not contain descriptions of other practices. Moreover, the interview is a material-discursive practice that contains interview talk materialized in embodied interaction between the interviewer and the interviewee. Furthermore, the discursive practice of the interview often has its origin in the material world, for example, in the desirable bodily features of the ideal employees. In a similar vein, discursive interview practices usually have material effects and consequences (Aarsand and Forsberg 2010; Barad 2007).

We started the actual process of analysis by extracting the quotes and passages in which the interviewees talked about issues relevant to our research questions. As our focus of analysis was on the informal practices of inequality in recruitment and selection, we concentrated first in text bits related to gender, ethnicity, and age that reflected tacit ideas about an ideal worker and ideal recruitment and selection. After that, we 
sorted these passages into three broader categories in order to analyze how these ideas became informal practices of inequality. At this stage the analytical focus shifted from gender, ethnicity, and age to the level of informal practices of inequality. The first such category relates to obeying and violating the equality legislation in general. The second category relates to questions of responsibility behind the recruitment practices, and focuses mainly on shifting the responsibility to someone other than the recruiter. The third category concerns the issue of diversity management in recruitment. The following empirical sections are based on these categories.

\section{Recruitment by the book}

When mapping out the practices of inequality in recruitment, we noticed that on a general level, the recruiters are well aware of equality legislation and they frequently describe their efforts to follow it. At the Department Store, for example, the human resources department is planning directions for everyone involved in recruitment processes that dictate what can and cannot be asked in job interviews according to equality legislation. The purpose of this is not only to promote equality, but also to prevent problems and possible litigation. The questions asked in the job interview are one central point through which the recruiters talk about equality.

One of the recruitment consultants pointed out that the job applicant need not answer every question he poses, although he never asks 'immoral questions,' as he put it. He describes immoral questions as basic questions such as whether the candidate smokes, what kind of hobbies s/he has, and other personal questions about her/his family situation. He describes these questions as immoral and irrelevant to recruitment and work commitment, but not as illegal questions. Another recruitment consultant explains that job applicants are not always completely truthful, and therefore they may need to be asked what he calls 'illegal questions':

Things aren't always like people tell us. I'm not saying that they systemically lie to us, but people present things in many ways, and sometimes their way is more favorable to them. It's typical that the job seeker, when $s / h^{1}$ is asked about things, answers from her/his point of view and how s/he saw events. I'm not saying that people lie to your face, but if the former employer is asked to describe the same event, for example, the former employer may have totally different view. So, how do I dig up these things with legal means? That is challenging. (Male recruitment consultant)

Here, the recruitment consultant indicates that he does not rely solely on only legal means, but he does not explain how illegal questions help to draw an honest picture about the job applicant's career. This idea of illegal questions recurs throughout the research interviews, and it is drawn from equality legislation. According to the Act on Equality (609/1986), women and men cannot be treated differently during the recruitment process. However, there is no such thing as illegal questions, but knowing the answers to certain questions and letting the information effect recruitment decisions could be discriminatory. Several recruitment consultants imply that they do not deliberately ask job seekers certain questions concerning their spouses, children, and other family issues. Instead, they expect these issues to be raised by the applicants themselves 
in the job interviews. In other words, the recruitment consultants expect to receive information about certain issues even though they do not pose questions that they think are illegal.

Furthermore, the recruitment consultants emphasize that their duty is also to prevent their clients from making clear and visible breaches of discrimination law, for example, in job advertisements:

Recruiter: Our duty is to be the middleman, and if the client presented things as they tell them to us and it got out somewhere, well, they would be breaking the law. I also direct the clients in what they can and you cannot do so, it doesn't get out. No matter what the law says ... This isn't going anywhere with my name on it, is it?

Interviewer: No.

Recruiter: $\quad$... so, no matter what the law says, there may be the recruiter's own view on what to do in the background. Only an idiot would write in a job advertisement that they are seeking a man or a woman or someone young or old. If somebody outside the selected demographic calls, they are answered anyway, 'Sure, send your application.' But their application stops there. So I don't know, it's discrimination like any other. But our job is to make sure our client doesn't mess these things up. (Male recruitment consultant)

Here, the recruitment consultant's motivation in obeying the law is to prevent the client from making mistakes that could potentially cause problems. The recruiters avoid inequality because they are obliged to do so by the law, not because they want to advance equality as such. Sexism, racism, and other forms of discrimination do not disappeareven though they are sanctioned by law-they just take a more discreet and hidden form (Husu 2002). Some of the interviewees are well aware of this, too. A man involved in recruitment at the Department Store says that the consequence of 'the Finnish [equality] legislation and democracy that has been taken to the extreme' is that people have become 'very, very cautious.' He continues:

Every time the equality card is played, for example, in this interview of yours [talks to the interviewer], it immediately makes me think 'whoops, let's not talk about this.' But at the same time I started to think about it one night, that like you said, the society that stares at stereotypes does the job for the employer, in a way. You don't want to tilt at windmills, either, because these stereotypes are shared. You know that you have a rocky road ahead if you are a man and you want to sell lingerie.

The interviewee suggests that there is a form of gender inequality which is not actively practiced by anyone. Instead, the culturally shared gender stereotypes that are reproduced through informal practices sustain gender inequality. Behind every recruitment process, there are always tacit ideas about what kind of body and personality is suitable for each job. For example, leadership is often defined through characteristics stereotypically connected with masculinity, such as authority, aggression, and competitiveness (Lepistö-Johansson 2009, p. 57; Meyerson and Fletcher 2000, p. 129). Therefore, there are always certain norms about the ideal worker for each job, even though the norms might not be explicit or even acknowledged. These norms are gendered: a leader is a 
man rather than a woman and a person who sells lingerie is rather a woman than a man. Moreover, differences in terms of ethnicity and age, for example, are included in these norms. When such norms are not made explicit and questioned, they continue to reproduce informal practices of inequality. When the focus is on obeying the law rather than on promoting equality, the central processes that produce inequalities remain untouched.

The recruitment consultants do not consider the applicants' gender to play a significant role in their work, although they admit that it may have an influence in recruitment in general. One of the recruitment consultants answered, 'Well, somehow I perhaps don't see that it has an effect-at least at a conscious level—but of course everybody may have these unconscious thoughts.' Instead, the job applicants' age is commented on more often than their gender.

In Finland, discrimination in recruitment on the grounds of age has been widely discussed in public debate. Age is generally seen as one of the most common factors in putting a person at a disadvantage in the recruitment process (Larja et al. 2012, pp. 39-51). One of the recruitment consultants very strongly believes that the discussion on ageism has gone too far. She says that all women-no matter what their age-think that if they are not recruited, it is precisely because of their age. She does not consider the job applicants' age a relevant issue, but says that age is presented as a reason why women are not recruited:

There is a lot of talk about ageism. I don't believe in it as strongly as you find when you follow the discussions. In some discussions it has been said that when you are over 40 , you are past it and thrown in the trash can. To me, it's like, 'hang on a minute, it can't be like that.'

However, it has been noted that clear age-discriminating recruitment practices exist in work organizations, which partly explains why re-employment is difficult among older workers (Pärnänen 2012). Some research findings also indicate that people in decisionmaking positions might have difficulties in admitting that age discrimination occurs (Larja et al. 2012, p. 41).

As we have demonstrated in this section, obeying the law does not guarantee an equality of outcomes. The recruiters are aware of equality legislation concerning recruitment processes, but their interpretation of the legislation is somewhat selective. They have internalized the letter of the law, but not its purpose, namely to promote equality. This is also a wider problem with equality policies in the Nordic countries. Attention is paid to statistics and measures, such as equality planning, and the reason why the laws are needed seems to be lost (Kantola 2010). These findings are consistent with the literature on legal awareness and penalty avoidance in organizations that confirms human resource specialists and managers to be conversant with the legal requirement, but also that formal regulations still have only limited efficacy in preventing inequality (e.g., Dickens 2007; Pratten and Lovatt 2005). If we want to promote equality, we need to tackle the informal practices that produce inequality.

\section{Relocation of responsibility}

Another informal practice of inequality in recruitment is shifting the responsibility for equal treatment to someone else, either to the job applicant or to the client. The 
recruitment consultants indicated that the job applicants' age and gender do not have an impact on their work, but many of them also pointed out that they do not make the final recruitment decision; the final say is ultimately the client's. The client as an employer may have completely different preferences to the recruitment consultants when it comes to the job applicants' age and gender:

\begin{abstract}
We aren't allowed to make any decision based on either these factors [gender or age]. But the fact is that the client usually makes the final recruitment decision, and those factors do have an effect. Maybe gender not so much, I would say, but age has a more concrete impact. One notices that unfortunately more experienced persons are easily dropped without any evident reason for why s/he is discarded, so the easy conclusion to draw is that her/ his age is an issue for the client. But gender definitely has an impact on some cases, too. We are not even allowed discuss this kind of thing with our client. If they try to discuss them, we make it loud and clear that this is our work, we need to be impartial and objective and that [these issues] cannot be the basis of a recruitment decision. And they know it pretty well. If they have any desire or need to base their decisions on this kind of issue, they make their decisions without telling us. (Male recruitment consultant)
\end{abstract}

The recruitment consultants were also asked if the job applicants' ethnicity is relevant in the selection process. The recruiters pointed out that some of the clients never hire an applicant with an ethnic background, and therefore it is pointless to introduce such applicants to these clients. Several recruitment consultants suspected that the employers' prejudice prevents applicants with an ethnic background from being hired:

But we have job seekers who have a foreign name and who speak perfect Finnish, so then perhaps there may be such prejudice, even when one can see that $\mathrm{s} /$ he has lived her/his whole life in Finland and went to school here, has been educated and worked in Finnish. So, there may be a little visible prejudice there. (Female recruitment consultant)

Ethnic origin or skin color is generally seen as an equally important factor as age in putting a person at a disadvantage in the recruitment process in Finland (Jasinskaja-Lahti et al. 2002, pp. 86-88; Larja et al. 2012, pp. 181-182). However, the recruitment consultants denied that the job applicants' ethnic background and, for example, skin color, had any significance in their assessment of the candidates. Instead, several recruitment consultants shifted the issue from the applicant's ethnic background to her/his language skills. They stated that if the job applicant's Finnish and English skills are not adequate, they cannot be hired for most jobs. It has been noted that a lack of language skills is a common reason to decline job applications from people from ethnic backgrounds, and sometimes this is done without foundation (Ahmad 2002; Rydgren 2004). Similarly, several recruitment consultants also shifted the discussion about the job applicants' embodied and cultural attributes to their insufficient language skills, which they regarded as an obstacle to recruiting immigrants. However, some of the recruitment consultants disagreed with this view, such as one male recruitment consultant: 'As a matter of fact, a pleasingly high number of immigrant employees are hired. Little by little, Finns are learning that speaking broken Finnish doesn't necessarily make a person a bad employee.'

Language skills were mentioned almost every time when HR managers talked about hiring immigrants at the Department Store. Language skills were given different meanings depending on whose language skills were discussed, where was the person from, 
what languages s/he could and could not speak, and which position s/he was applying for. In many cases, the HR managers at the Department Store stressed that language skills are not an issue in recruitment:

We think it's so nice, we should have even more [immigrants]. Language has never been an issue here. We have seen it as a chance to develop, that we can use English, for example. A good example is our [middle manager] who is Swedish and really only speaks few words of Finnish, and when we recruited him, we recruited people under him on the basis on their strong skills in English so that they would be able cope with their manager. So, we see it as a positive challenge.

The experiences of the people who worked for non-Finnish managers were less positive: they felt the language differences caused misunderstandings in everyday work and made their job harder. If the person with no skills in Finnish language was their peer, they viewed the situation less problematically. Nevertheless, the immigrants at the Department Store who felt their language skills were not an obstacle in their career all worked in managerial positions and came from Western countries. Conversely, the immigrants of Asian, African, or South American origin felt their opportunities to advance in their career were much poorer (also Jasinskaja-Lahti et al. 2002, pp. 86-88). They all thought the Department Store treated them very fairly, but their less than perfect skills in Finnish were a problem. For example, an Iraqi man who served customers in Finnish and spoke it well enough to be interviewed about equality issues felt that he would not have a chance to apply for a more senior position until he spoke much better Finnish.

Language skills are a legitimate reason for some of the inequalities in the workplace, and in the labor market in general (Ahmad 2002). The criteria for adequate language skills are not explicit. Instead, it is rather vague, sometimes even a question of foreign accent (Näre 2013, pp. 76-77). However, it is gladly applied by the HR managers, supposedly because the responsibility for equal treatment can be relocated from the employer to the employee: learning the requisite language skills is the responsibility of the person recruited. Job applicants also willingly take this position-perhaps because they have no choice. An immigrant male employee with a university degree, working in a relatively low position, stated: 'It's the same in every country when you are foreign. If you don't manage the language perfectly, you have to usually to start from the bottom, but you have to deal with it.'

Language skills may be the most commonly mentioned reason for not recruiting an immigrant, but it is not the only one. One of the recruitment consultants pointed out that the immigrant's working style may not fit in at the organization, and therefore the employer would not want to hire the applicant. Obviously, one could ask how the employer could be familiar with the job applicant's working style when the applicant has not worked for the employer. Other recruitment consultants said that employers have had bad experiences of immigrant employees, and therefore they refuse to hire them. Another issue brought up was that immigrants do not write their résumés in the same way as Finnish job applicants, and this complicates the recruitment consultants' work: 'Finns rarely exaggerate in their résumés. Their [the immigrants'] résumés are "I'm super, the best in the world at this." But that's not the reality.'

Thus, at the same time as the recruitment consultants are doing service work for their clients, they are keeping the clients satisfied with their services. This involves 
relocating the responsibility of inequality to the client. At the Department Store, the responsibilities are different since the firm has not outsourced recruitment. However, in both instances the intention to relocate responsibility from the recruiters to client or to job applicants themselves is clear.

\section{Recruiting by addressing difference}

Several HR managers at the Department store stated it was the policy of the organization that the ethnic, gender, age, and educational background of the applicant is unimportant. For example, a high level of education is not required for managerial positions. Work experience-in terms of know-how and competence-and 'the right attitude' are given priority in the recruitment process. The latter refers to applicants' personality and social suitability. Social and personal skills and behavioral competencies are difficult to evaluate, even when personal testing is used. In practice, it is often a question of the recruiters' or job interviewers' preferences and chemistry in concrete face-to-face job interview situations. In the recruitment process, the context of the recruiter and applicant's meeting is meaningful, since tacit ideas of the ideal worker are involved (Callaghan and Thompson 2002, pp. 234-235).

The Department Store had hired some immigrant workers for whom the position was in many cases their first job in Finland. The research interviewees-both those who are involved with recruitment and those who are not-spoke about diversity as an advantage to both the company and to the employees. This differed from the frames we have analyzed earlier in this article, because here recruiting a diverse set of people was seen as something positive rather than as a risk. This position comes close to a diversity management framework.

It has been stated that in Finland, gender equality is a much stronger discourse than diversity management (Tienari et al. 2009). Gender equality is justified by fairness, equal opportunities, and equality legislation and it is this equality discourse that frames diversity management discourse in Finnish organizations. None of the interviewed HR managers in this study were familiar with the concept of diversity management, although they were familiar with its content. Diversity management was framed by the discourse of marketization, as can be seen in the quotation below. The HR manager explains why she finds diversity to be 'a richness' for a company, and why she thinks the company should recruit a diverse workforce:

Things don't advance if people are the same and think the same way. We need people who challenge the status quo, who see things maybe a bit differently. If their background is different and they can see things that the others do not necessarily pay attention to, as long as they can deliver their own know-how and vision to the department ... And, of course, our clients are different, so perhaps we can serve them better through this too.

Here, different types of workers are seen as representing different types of ideas and different types of clients. The background of the employees is considered to enable them to see things differently. Through their know-how and vision, the company is able to address the diversity of their customers and perhaps to serve them better. In the extract, diversity as difference is seen as a positive challenge for the organization. However, one 
can ask, what if the perceived differences in the employees' backgrounds do not generate new ideas and better service solutions? How is difference thought to operate, and what kind of difference is important? According to this perspective, customers benefit and companies develop as a result of employing a diverse, value-adding workforce, but the personnel themselves do not benefit. Equality is reduced to a question of what diversity has to offer the organization. It is therefore pertinent to question the kind of equality this sort of approach promotes.

Diversity was also seen as adding value by hiring immigrants. The employer can benefit from immigrant job applicants' weak position in the Finnish labor market. Given this leverage, it is possible to find employees who expect less and deliver more:

Frankly, I have been disappointed more often with a presentable individual, because s/he has higher expectations about the job to begin with. A person who hopes for an opportunity is more open to what the job can offer, they don't see everything already like 'this was [better] in my previous job.' Their mind is more open.

This extract shows that what is expected of employees varies according to their background: people who find it difficult to get a job in the Finnish labor market-such as immigrants and elderly workers-might be expected to settle for less than those who are more likely to find a job elsewhere. It is in the organizational self-interest to focus their recruitment policy on workers lacking in power within the labor market. This is in line with earlier observation that migrant workers were feted as valuable resource because of their attitudes as well as work ethics, but management's praising of the virtues of the migrant workers was based on the business case and possibility to continue minimal statutory compliance (MacKenzie and Forde 2009).

The quotation above is illustrative also in terms of the interviewee's choice of words. The term 'a presentable individual' can be seen as an evaluative statement, according to which a Finnish applicant that is more educated and probably therefore in possession of more social and cultural capital is valued higher, yet in this case, the interviewee was not always satisfied with them. The choice of words embodies a way of reproducing hierarchy between different social groups.

A problem with diversity management is that when a diverse workforce is hired in the name of profitability instead of equality, it may lead to reinforcing certain informal practices of inequality while perhaps demolishing others. To promote equality, diversity should rather be seen from an equality rather than a management perspective. The Department Store has taken small steps toward equality-for example, including multiculturalism and equality in the organization's values is a significant step. Nevertheless, there are different levels in understanding diversity, and the Department Store's process of advancing equality in parallel with diversity is still a work in progress in terms of the espoused values of the company's personnel policy and everyday work practices.

\section{Discussion and conclusions}

In this article, we have explored the recruitment and selection policy and processes from the perspective of inequality and investigated the kinds of tacit ideas held about the ideal 
worker that lie behind the recruitment and selection policy and practices of HR managers and recruitment consultants. These ideas are an example of processes and practices that contribute to the production of inequality regimes in organizations.

Recruiters aim to find the most suitable people for particular jobs and positions. The most suitable person varies from one job and position to another, and such qualifications are often explicit. Nevertheless, in every job there are tacit ideas about the ideal worker, and they are permeated by social divisions, such as gender, age, and race or ethnicity. The ideal worker has a certain gender, age, and nationality, although this is not a static category but varies over time and place (Tienari et al. 2002). The curious thing about the ideal worker's gender is that the recruiters admit gender does matter in recruitment, but they do not say which gender is preferred. This might be because different jobs are considered suitable for women or men. Jobs considered more suitable for women are usually lower in the hierarchy (Johansson 1998, p. 55). 'Female jobs' are more often low-paid than the 'male jobs,' and the tasks are considered to be simpler in such female jobs (ibid.) Therefore, hiring the most suitable woman or a man for a certain job very often reinforces gendered hierarchies in working life.

The age of an ideal worker was a more contested topic. The recruiters questioned what they thought was the general opinion about the ideal age for an employee, namely that the ideal worker should be under forty years old. Although the recruiters disagreed on this, age discrimination is still widely reported in Finland (Larja et al. 2012). The age limit of forty for the ideal worker is so well known that it might affect the practices of recruitment, even though the recruiters contested it.

The ethnicity of the ideal worker was clearer, although it was often disguised as a question of language skills. The ideal worker speaks perfect Finnish, regardless of the language requirements of the job. However, language requirements are interpreted flexibly. It was not a problem to hire a Swedish manager who did not speak any Finnish at all, while for an Iraqi man working in customer service, not speaking perfect Finnish was perceived to be a barrier in his career. The ideal worker is thus of a certain ethnic background; our data does not allow us to elaborate on this more thoroughly, but this could be an important subject for future study.

We have also asked how these ideas and the implicit settings of day-to-day interaction concerning recruitment become informal practices of inequality, that is, practices that sustain inequality in work organizations. We classified these into three different categories of informal practices of inequality that were recruitment by the book, relocation of responsibility, and recruiting by addressing the difference.

Firstly, we found that the recruiters were aware of the equality legislation concerning equal treatment in recruitment, and they tried to obey the law. However, their own or their clients' ideas about the ideal worker for a certain job were sometimes in conflict with equality legislation, and in such cases they interpreted the legislation somewhat selectively. The recruiters did not obey the law because they wanted to promote equality in itself-which is, after all, the purpose of the equality legislation-but rather because they wanted to avoid problems and possible litigation. Equality legislation in Finland is based on recommendations and voluntary practices rather than on prohibitions and sanctions (Kantola 2010). Due to this state of affairs, it is possible to obey the law but at the same time reinforce informal practices of inequality in recruitment that create systematic disparities between different social groups. Therefore, the selective interpretation of the equality legislation is one informal practice of inequality. 
Secondly, we found that the recruiters shifted the responsibility for equal treatment onto someone else-either onto the job applicant or onto the client, that is, the organization that is hiring the person. The recruiters claimed that the job applicants should acquire certain skills, or that the organizations should change their requirements for the suitable people so that they, as recruiters, could make more equal decisions in the recruitment processes. Shifting responsibility allowed the recruiters to carry on the practices and processes of recruitment and selection in a way that reproduced inequalities while being 'pro-equality' at the same time. Shifting the responsibility for equal treatment onto someone else was therefore another informal practice of inequality.

Thirdly, although there are informal practices of inequality in recruitment, the HR managers celebrated diversity because it was an important value for the company they were working for-and perhaps for the HR managers themselves. However, diversity was seen as valuable mainly because it benefited business. Different people were seen as a source of different ideas and they enabled serving different clients better. Here, as with the creative interpretations of the equality legislation, promoting equality was not seen as the goal as such. Rather, equality (in the form of celebrating diversity) was seen valuable only if it benefited business. Sometimes making diversity a business benefit led into unequal treatment. For example, immigrants were hired for low hierarchy jobs because they expected less and delivered more than Finns. In such cases, making diversity a business benefit was an informal practice of inequality.

The three analyzed categories-recruitment by the book, relocation of responsibility, and recruiting by addressing the difference-can be seen representing practices that produce inequalities into recruitment, and therefore in the framework of inequality regimes, result in and maintain gender, age, and ethnic inequalities in the Finnish work organizations. The idea of inequality regimes is a conceptual strategy for not only understanding the mutual reproduction of gender, race, and class inequalities in organizations, but also for assessing the possibilities for reducing inequalities in particular organizations. Inequality regimes tend to be fluid and changing, which opens up space for change. The informal practices we have described are informal and subtle, and therefore they could be very difficult to challenge. The equality legislation in Finland was renewed in 2014, which may bring about some changes in inequality regimes. Nevertheless, as we have demonstrated here, formal practices, such as legislation, cannot change informal practices of inequality alone. Changing inequality regimes calls for active work for equality on the individual, organizational, and societal level.

Even though it is not possible to generalize our findings literally into the whole Finnish labor market, we believe that the findings being consistent with previous research indicate the order of the day in recruitment. Our results involve the aspects of a penalty avoidance and relocation of responsibility that might help the clients of the recruitment consultants to perpetuate their long-standing prejudices based on stereotyping without helping to enhance their HR attributes and perspectives. However, what we clearly miss is more knowledge which helps us to understand the impact of the outsourcing of the recruitment practice in maintaining inequality.

\section{References}

Aarsand, P. and Forsberg, L. (2010) Producing Children's Corporeal Privacy: Ethnographic Video Recording as Material-Discursive Practice. Qualitative Research 10(2): 249-268. 
Acker, J. (1990) Hierarchies, Jobs, Bodies: A Theory of Gendered Organizations. Gender and Society 4(2): 139-158.

Acker, J. (1992) Gendering Organizational Theory. In Mills, Albert J. and Tancred, Peta (eds.) Gendering Organizational Analysis. Newbury Park: Sage, 248-260.

Acker, J. (2006a) Inequality Regimes. Class, Gender and Race in Organizations. Gender \& Society 20(4): 441-464.

Acker, J. (2006b) Class Questions, Feminist Answers. New York: Rowman \& Littlefield Publishers.

Acker, J. (2009) From Glass Ceiling to Inequality Regimes. Sociologie du Travail 51: 199-217.

Acker, J. (2011) Theorizing Gender, Race, and Class in Organizations. In Jeanes, Emma, Knights, David and Martin, Patricia Yancey (eds.) Handbook of Gender, Work and Organization. Wiley: Chichester.

Act on Equality between Women and Men (609/1986). Available: http://finlex.fi/en/laki/ kaannokset/1986/en19860609.pdf [Jan 9, 2015].

Ahmad, A. (2002) Yhteisten työmarkkinoiden erottelemia? Maahanmuuttajien työllistymismahdollisuudet suomalaisilla työmarkkinoilla. [Separated by Common Labor Market? Immigrant's Employment Possibilities in Finnish Labor Market] Sosiologia 39(3): 227-241.

Åslund, O. and Nordström Skans, O. (2012) Do Anonymous Job Application Procedures Level the Playing Field? Article 5. ILR Review 65(1): 82-107.

Barad, K. (2007) Meeting the Universe Halfway: Quantum Physics and the Entanglement of Matter and Meaning. Durham: Duke University Press.

Beattie, G. and Johnson, P. (2012) Possible Unconscious Bias in Recruitment and Promotion and the Need to Promote Equality. Perspectives: Policy and Practice in Higher Education 16(1): 7-13.

Breaugh, J.A. and Starke, M. (2000) Research on Employee Recruitment: So Many Studies, So Many Remaining Questions. Journal of Management 26(3): 405-434.

Brunila, K. (2009) Parasta ennen. Tasa-arvotyön projektitapaistuminen. [Best Before. The Projectization of Equality Work.] Helsinki: University of Helsinki.

Callaghan, G. and Thompson, P. (2002) We Recruit Attitude': The Selection and Shaping of Routine Call Centre Labour. Journal of Management 39(2): 233-254.

Carlsson, M. and Rooth, D.-O. (2007) Evidence of Ethnic Discrimination in the Swedish Labor Market Using Experimental Data. Labour Economics 14(4): 716-729.

Chapman, D., Uggerslev, K., Carroll, S., Piasentin, K. and Jones, D. (2005). Applicant Attraction to Organizations and Job Choice: A Meta-analytic Review of the Correlates of Recruiting Outcomes. Journal of Applied Psychology 90(5): 928-944.

Choo, H.Y. and Ferree, M.M. (2010) Practicing Intersectionality in Sociological Research: A Critical Analysis of Inclusions, Interactions, and Institutions in the Study of Inequalities. Sociological Theory 28(2): 129-149.

Dickens, L. (2007) The Road Is Long: Thirty Years of Equality Legislation in Britain. British Journal of Industrial Relations 45(3): 463-94.

Gilbert, J.A., Stead, B.A. and Ivancevich, J.M. (1999) Diversity Management: A New Organizational Paradigm. Journal of Business Ethics 21(1): 61-76.

Healy, G., Bradley, H. and Forson, C. (2011) Intersectional Sensibilities in Analysing Inequality Regimes in Public Sector Organizations. Gender, Work \& Organization 18(5): 467-487.

Husu, L. (2002) Piilosyrjintä akateemisessa maailmassa: tiedenaisten vai tiedeyhteisön ongelma? [Hidden Discrimination in Academic Word: The Problem of Academic Women or Academic Community?] Naistutkimus- Kvinnoforskning 15(1): 48-52.

Jasinskaja-Lahti, I., Liebkind-Ormala, K. and Vesala, T. (2002) Rasismi ja syrjintä Suomessa. Maahanmuuttajien kokemuksia. [Racism and Discrimination in Finland. Immigrants' Experiences.] Helsinki: Gaudeamus. 
Johansson, U. (1998) The Transformation of Gendered Work: Dualist Stereotypes and Paradoxical Reality. Gender, Work and Organization 5(1): 43-58.

Julkunen, R. (2010) Sukupuolen järjestykset ja tasa-arvon paradoksit. [Gender Orders and Equality Paradoxes.] Tampere: Vastapaino.

Junnila, K. and Honkaniemi, L. (2010) Organisaatioiden rekrytointikäytännöt. Kyselytulokset syksyltä 2009, yhteenveto Työterveyslaitos ja HENRY ry. [Recruiting Practices in Organizations. Survey Results in 2009.] Helsinki: Työterveyslaitos.

Kandola, R. and Fullerton, J. (1998) Managing the Mosaic: Diversity in Action. London: Institute of Personnel Development.

Kantola, J. (2010) Gender and the European Union. Basingstoke: Palgrave Macmillan.

Keep, E. and James, S. (2010) Recruitment and Selection. The Great Neglected Topic. SKOPE Research Paper No. 88. Cardiff: Cardiff University.

Larja, L., Warius, J., Sundbäck, L., Liebkind, K., Kandolin, I. and Jasinskaja-Lahti, I. (2012) Discrimination in the Finnish Labor Market-An Overview and a Field Experiment on Recruitment. Helsinki, Publications of Ministry of Employment and the Economy, Employment and Entrepreneurship 16/2012.

Lepistö-Johansson, P. (2009) Mistä on naisten johtajaidentiteetit tehty? [What Are Women's Leadership Identities Made of?] Naistutkimus-Kvinnoforskning 22(3): 56-59.

Lorbiecki, A. and Jack, G. (2000) Critical Turns in the Evolution of Diversity Management. British Journal of Management 11(1): 17-31.

MacKenzie, R. and Forde, C. (2009) The Rhetoric of the 'Good worker' versus the Realities of Employers' Use and the Experiences of Migrant Workers. Work, Employment \& Society 23(1): $142-159$.

Meyerson, D. and Fletcher, J.K. (2000) A Modest Manifesto for Shattering the Glass Ceiling. Harvard Business Review 78(1): 126-136.

Näre, L. (2013) Ideal Workers and Suspects: Employers' Politics of Recognition and the Migrant Division of Care Labour in Finland. Nordic Journal of Migration Research 3(2): $72-81$.

Non-discrimination Act (1325/2014). Available: https:/www.finlex.fi/fi/laki/kaannokset/ 2014/en20141325.pdf [Aug 20, 2015].

Nordin, M. and Rooth, D.-O. (2009) The Ethnic Employment and Income Gap in Sweden: Is Skill or Labor Market Discrimination the Explanation? Scandinavian Journal of Economics 111(3): 487-510.

Pärnänen, A. (2012) Does Age Matter in HR Decision Making? Four Types of Age Policies in Finnish Work Organizations. Nordic Journal of Working Life Studies 2(3): 67-88.

Pratten, J.D. and Lovatt, C.J. (2005) The Impact of Employment Legislation on Micro Businesses. Journal of Small Business and Enterprise Development 12(2): 290-300.

Quality of Work Life Survey (2013) Discrimination at Workplaces. Helsinki: Statistics Finland. Available: http://www.stat.fi/til/tyoolot/2013/02/tyoolot_2013_02_2014-05-15_ kat_001_en.html_[Dec 5, 2014].

Rooth, D.-O. (2010) Automatic Associations and Discrimination in Hiring: Real World Evidence. Labour Economics 17(3): 523-534.

Rydgren, J. (2004) Mechanisms of Exclusion: Ethnic Discrimination in the Swedish Labour Market. Journal of Ethnic and Migration Studies 30(4): 697-716.

Shen, J., Chanda, A., D’Netto, B. and Monga, M. (2009) Managing Diversity through Human Resource Management: An International Perspective and Conceptual Framework. The International Journal of Human Resource Management 20(2): 235-251.

Skjeie, H. and Teigen, M. (2005) Political Constructions of Gender Equality: Travelling Towards ... a Gender Balanced Society? Nordic Journal of Women's Studies 13(3): 187-197. 
Tienari, J., Quack, S. and Theobald, H. (2002) Organizational Reforms, 'Ideal Workers’ and Gender Orders: A Cross-Societal Comparison. Organization Studies 23(2): 249-279.

Tienari, J., Holgersson, C., Meriläinen, S. and Höök, P. (2009) Gender, Management and Market Discourse: The Case of Gender Quotas in the Swedish and Finnish Media. Gender, Work and Organization 16(4): 501-521.

Viitasalo N. (2011) Ikääntyvien kokema syrjintä työssä: Ikäsyrjinnän yleisyys ja ennustajat. [The Ageing Employees' Experiences of Discrimination: The Frequency and Prediction of Age Discrimination.] Työelämän tutkimus 9(3): 256-271.

World Economic Forum (2013) Global Gender Gap Report. Available: http://www3. weforum.org/docs/WEF_GenderGap_Report_2013.pdf [Nov 1, 2014].

\section{End note}

${ }^{1}$ The Finnish language uses the same word for 'she' and 'he' (hän). This is why we cannot always tell whether the interviewees are talking about female or male job seekers. To keep both options open, we have included both genders in the excerpts. 